\title{
The structure of John 17
}

\author{
C H Wong ${ }^{1}$ \\ (University of Pretoria)
}

ABSTRACT

\section{The structure of John 17}

This article proposes a structure for John 17. In paragraph A (1-5), Jesus prays for the glorification/revelation of the Father and the Son, so that Jesus' followers may have eternal life. This objective is achieved in Paragraph B (6-10) through the giving of God's words, resulting in the manifestation of Jesus' glory in them. Paragraphs 3, 4, and 5 contain three petitions: "Keep them in your name" (11-13), "keep them from the evil one" (14-16), and "sanctify them in the truth" (17-19). The goal of these petitions is that they may be one with God, as the Father and the Son are one (11e, 21a). This request for oneness is repeated in Paragraph 6 (20-23), but here the petition is for all believers. Jesus' revelation of the Father's name has brought about oneness, since God's love and Jesus himself have come to dwell in believers (Paragraph 7 [24-26]).

\section{INTRODUCTION}

John 17 has been called "one of the most majestic moments in the Fourth Gospel" (Brown 1970:744). It is a fitting climax to the Farewell Discourse(s). Brown (1970:587) remarks that the redactor "showed a touch of genius in putting it at the end of the Discourse. Its soaring, lyrical quality provides a perfect climax, whereas almost any other unit that could have been added here might have been flat and anticlimactic". John 17 is in many respects a summary of the Fourth Gospel from the first chapter through the sixteenth (Cadman 1969:203; Carson 1991:551; Dodd 1995:417; Käsemann 1968:3). "Almost every verse contains echoes" (Dodd 1995:417). The main themes include the mutual glorification of the Father and the Son, the Son's work of revealing the Father, the identity of Jesus as the sent one, the importance of receiving the words of Jesus, the world's hate, the love of God, Jesus' departure to the Father, the gift of eternal life, the mission of the disciples, and mutual indwelling. This chapter "forms a climax" in the Fourth Gospel, following the Farewell Discourse(s) and preceding Jesus' arrest and passion (Schnackenburg 1987:167). In the present configuration of the gospel, there is no more suitable place for this prayer and there

1 Post graduate student of Prof J G van der Watt, Department of New Testament Studies, University of Pretoria. 
would also be no better place in a possible original form of the gospel. It would also be out of the question to place it in front of the farewell discourse in Chapter 14 (that is, between 13.30 and 31), because such a climax has to occur at the end of all the discourses (Schnackenburg 1987:167; Brown 1970:745; Schnackenburg, Brown, and others disagree with Bultmann [1971:460-461], who thought Chapter 17 belongs best at the beginning of the Farewell Discourses).

Since glory is a dominant theme in this prayer, "The Prayer of Glorification" would be an appropriate title. Bultmann (1971:490) comments: "The decisive hour has come. To fulfil its purpose, it must become the hour of glorification (12.23); this is the first petition of the prayer, and is in fact its whole contents."

The words Tavi $\alpha \dot{\epsilon}^{\prime} \lambda \alpha^{\prime} \lambda \eta \sigma \in \nu$ in 17.1 connect the prayer to the Farewell Discourse(s). One of the features of OT and extra-biblical farewell discourses is that the speaker often concludes with a prayer for those who are left behind (e.g., Dt 32-33; 4 Ezr 8.19b-36; Jub 22.28-30) (Brown 1970:600; Beasley-Murray 1987:293; Carson 1991:550-551. The logical place for such a prayer is at the end of a farewell address, not before (Brown 1970:745). The dominant theme of glorification in the prayer connects it with 13.31-32 (Schnackenburg 1987:167), 14.12-13, 15.5, 8, and 16.14-15. Moreover, this prayer may be seen as the climax of both the Farewell Discourse(s) and the Fourth Gospel itself (Schnackenburg 1987:167; Dodd 1953:420).

\section{STRUCTURAL ANALYSIS OF JOHN 17}

A discourse is not composed of merely a series of isolated phrases, clauses, and sentences, since sentences, formed by the joining of phrases and clauses, are always combined into paragraphs, paragraphs into sections or chapters, and chapters into a discourse. A paragraph is a "thematic or semantic unit" (Louw 1982:116), by which a writer declares that "this much of my thought I wish you to consider separately from the rest because it seems to me to have a particular unity and to advance the idea in a peculiar way" (Jordan 1965:121). A paragraph is "often marked in a formal way ...by transitional particles, repeated words, parallel or chiastic structures, or introductory and/or terminal statements" (Louw 1982:116). The theme of a paragraph may be stated at the beginning, the end, the middle, or both at the beginning and at the end of the paragraph. "What is important is not so much the type of structural pattern of a 
paragraph, but rather the extent of its internal semantic unity in contrast with preceding and following thematic units or paragraphs" (Louw 1982:117). Louw's method of semantic analysis will be followed, and in this method one begins with an analysis of the internal structure of each thought unit (sentence or clause). This is followed by a determination of the relationships between the thought units. The resulting syntactic structure will give a basis for interpreting the text semantically. Below is a diagram showing the structure of Jn 17, indicating the paragraph divisions and the relationships between the thought units in each paragraph.

In paragraphs $\mathrm{A}$ and $\mathrm{B}$, the theme is stated at the beginning and the end of the paragraph. In paragraphs $\mathrm{C}, \mathrm{D}$, and $\mathrm{F}$, the theme is found in the middle of the paragraph. In paragraph $\mathrm{E}$ the theme is given at the beginning. In paragraph $\mathrm{G}$, there seem to be two main themes, one given at the beginning and one at the end of the paragraph. The glorification/revelation of God, which is the main theme of Chapter 17, results in the disciples' knowing God and becoming one with God. 


\section{Chart 1. Structural Analysis of John 17}

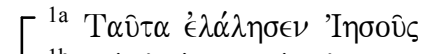

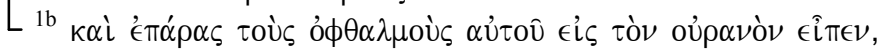
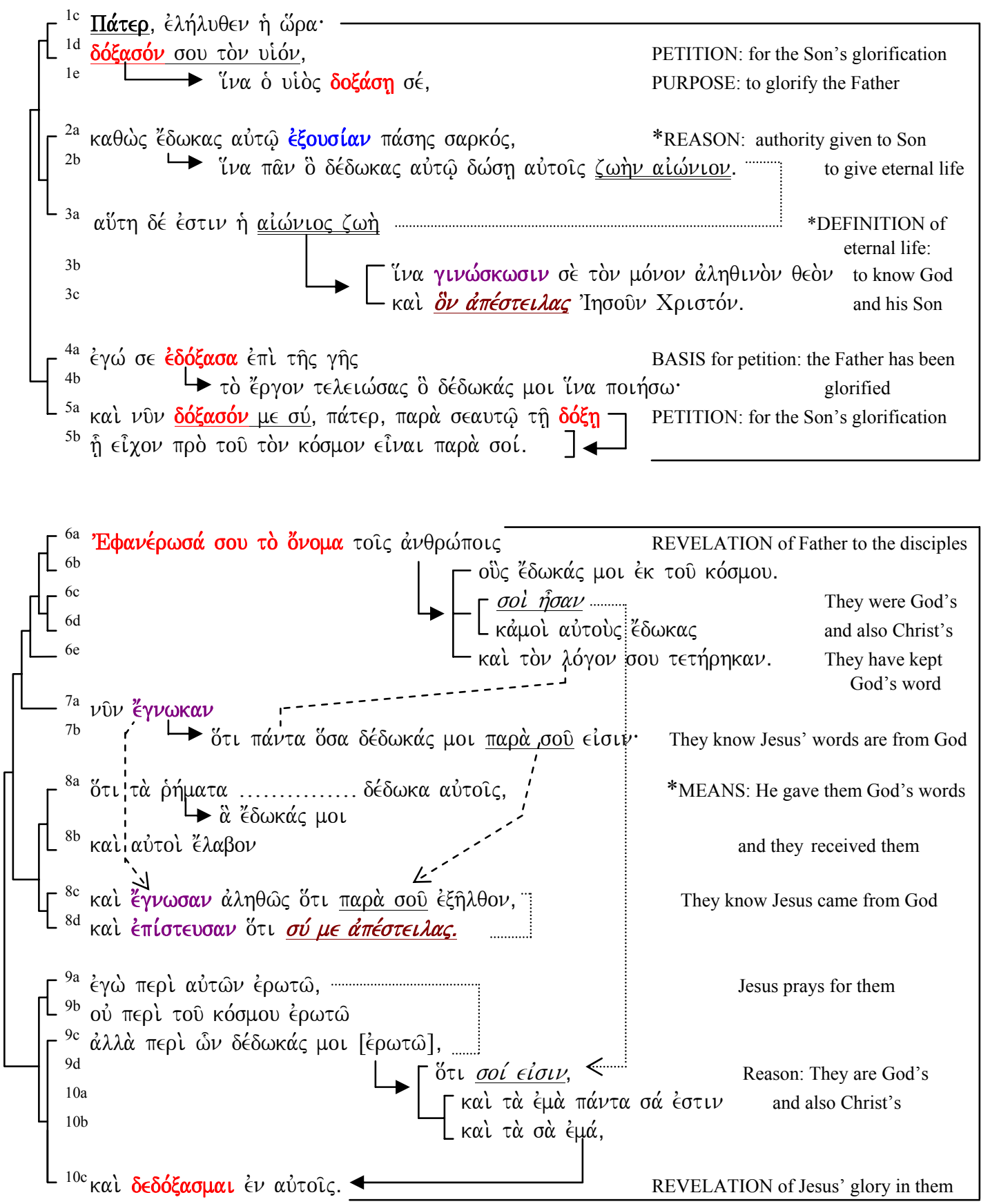

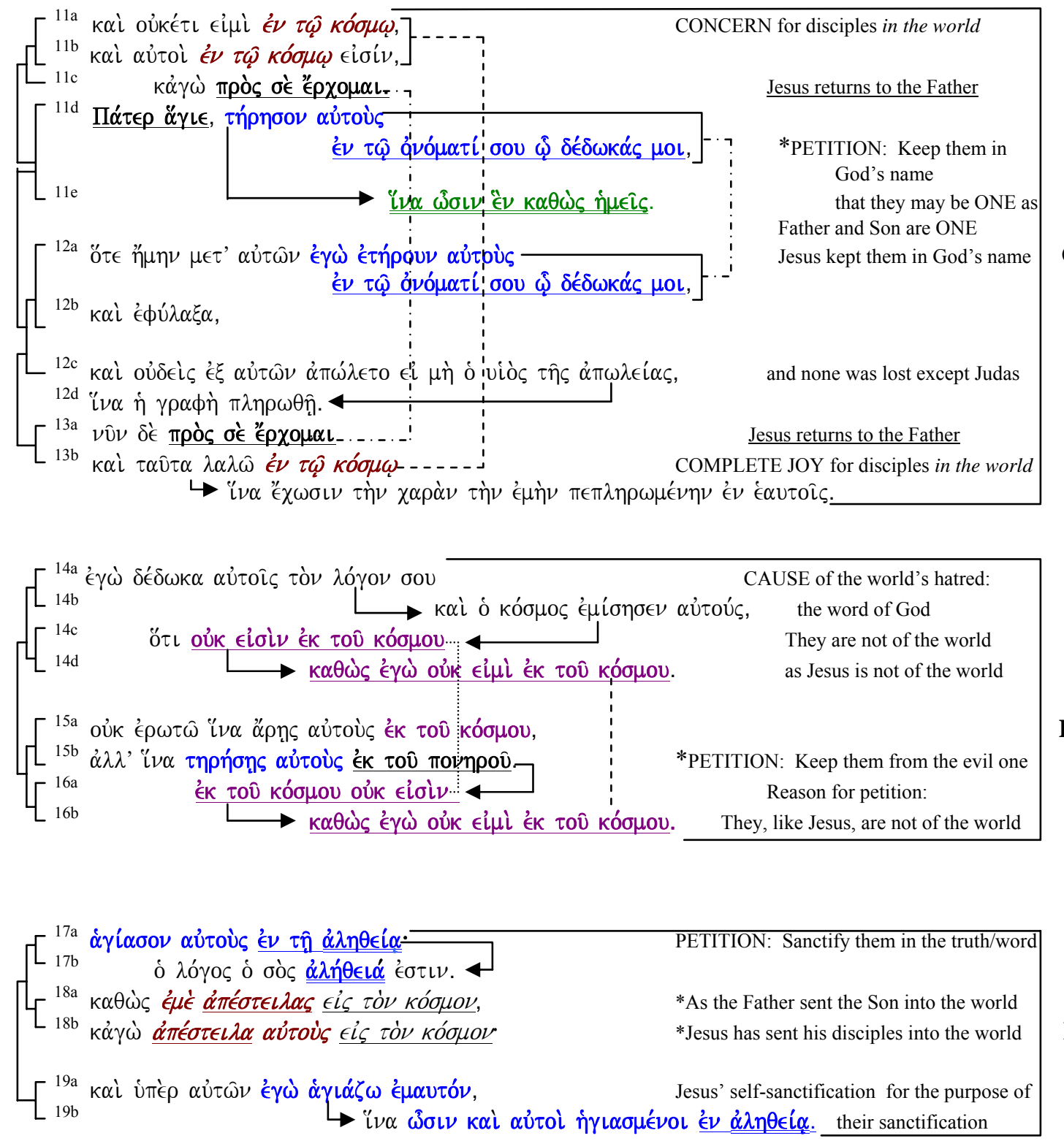

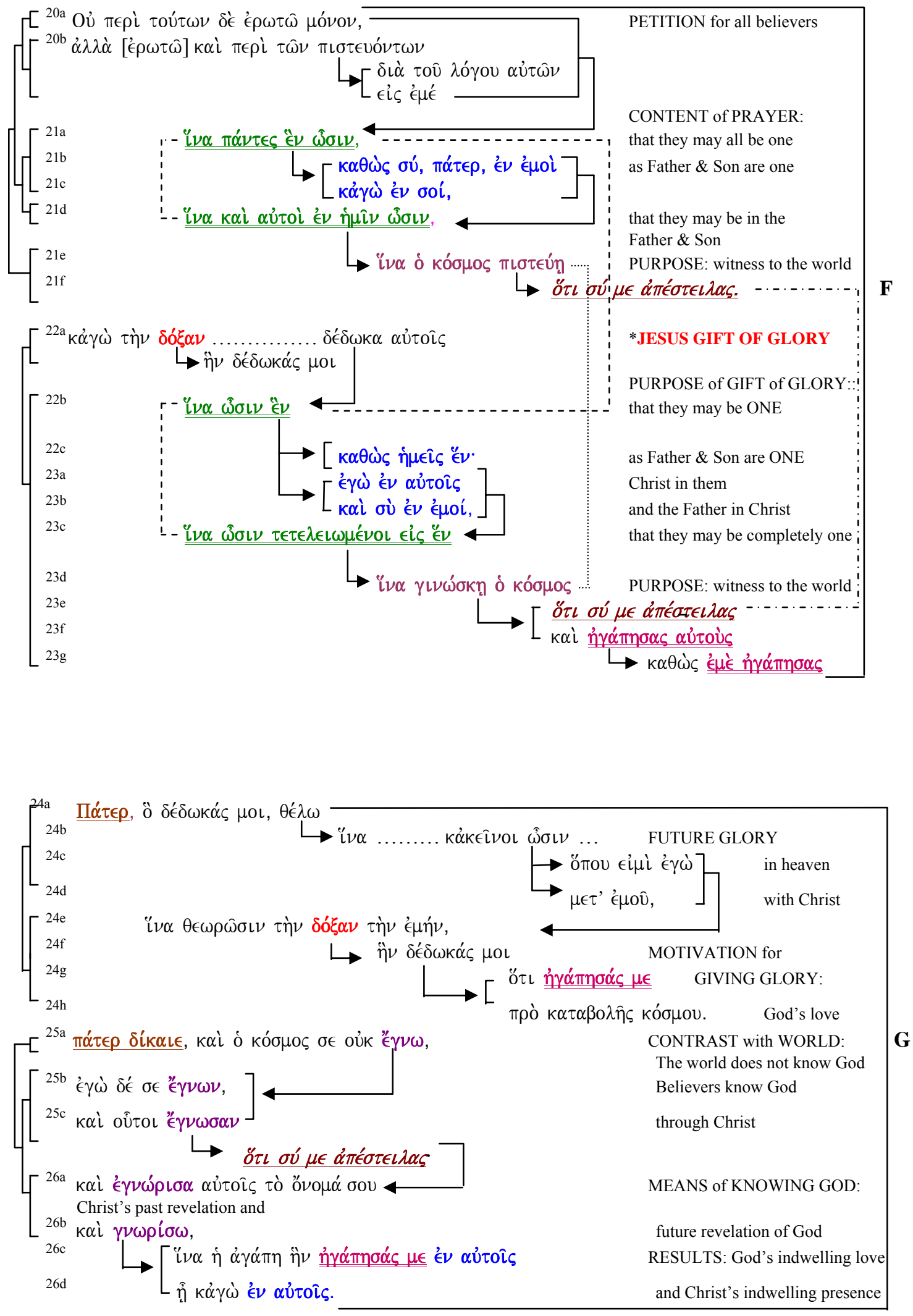
The structural analysis of Jn 17 (above) shows that there are seven divisions: 1-5, 6-10, 11-13, 14-16, 17-19, 20-23, and 24-26. Many Johannine interpreters recognize the poetic style of Jn 17 (Brown 1970:748)*. Recognition of the genre of a text can make a difference in interpreting the text (Van der Watt and Kruger). Reventlow (1999:27) states that poetic language is "intentionally imprecise" and cannot be analyzed "as if it were a scientific report." "Poetry thrives on allusions, on impressions which touch the feeling, never using explicit definitions, but rather hints referring to a knowledge hidden in the subconscious of the hearers" (Reventlow 1999:30). Black (1996:222) compares Johannine discourse to classical rhetoric, especially to the style called "grand," in which the diction is "plastic,... like wax that can be molded into various animal shapes" and where one finds "a heightening of effect" and "an extension of thought," in which the author dwells on an argument in order to strengthen it, presenting a series of impressive thought-units, each one of greater importance than the preceding (Black 1996:225).**

\subsection{Previously proposed structures}

Brown (1970:748) comments that on the basis of the apparent poetic style, one might expect "a careful structure." As it turns out, numerous different structures have been proposed and defended (Brown 1970:748). Two commonly suggested schemes have four divisions: 1-5, 6-19, 20-23, 24-26 (Lagrange 1948:436; Lindars 1995:515) and 1-5, 68, 9-19, 20-26 (Dodd 1995:417). Barrett (1978:499) offers a different fourfold scheme: 1-5, 6-19, 20-24, 25-26 (The NRSV follows this same

*Brown writes: "Even many of the scholars who do not find a poetic format in the Johannine discourses in general recognize the poetic style of xvii." Among the scholars who acknowledge that one or more sections of the Fourth Gospel contain poetic language are Beasley-Murray (1987:xxxviii); Brown (1970:cxxxii-cxxxv); Bultmann (1971:14-15); Robert Kysar 1992; Schnackenburg 1987:224-226; Smith 1965:23-24.

**Some of the features of this style of rhetoric found in the Fourth Gospel are structural balance, thoughts and words presented in parallelism, antithesis, repetition with or without always adding a new element, antanaclasis (the "punning repetition of a word in two different senses"), polysyndeton, asyndeton, and the interchange of words which are semantically close (Black 1996:225-226). 
scheme). Carson's (1991:553-569) fourfold division is like the first one, but the second unit is divided into three sections:

1. Jesus prays for his glorification 1-5

2. Jesus prays for his disciples 6-19

a. Jesus' grounds for this prayer 6-11a

b. Jesus prays that his disciples may be protected $11 \mathrm{~b}-16$

c. Jesus prays that his disciples may be sanctified 17-19

3 . Jesus prays for those who will believe 20-23

4. Jesus prays that all believers may be perfected so as to see Jesus' glory 24-26.

Brown (1970:750) has indicated that the main point of difference between the commonest fourfold and threefold divisions has to do with $6-8$, the section about the faith of the disciples. The question is whether this should be an independent unit (Dodd, above) or should be attached to 1-5 (Brown, below) or to 9-19 (Carson, above). Another point of difference, which Brown neglects to mention, has to do with 20-26, which Dodd and Brown consider one division, but others divide into two units, with the break coming either between 23 and 24 (Lagrange, Lindars, Carson) or between 24 and 25 (Barrett).

Brown (1970:749) favors a threefold division, partly because the sections are more nearly equal in length than in the fourfold schemes and partly because he sees "clear dividing marks in 9 and 20." Here is Brown's structure:

1-8: Jesus Asks for Glory on the Basis of His Work of

Revelation among the Disciples

9-19: Jesus Prays for Those Whom the Father Has Given Him 20-26: Jesus Prays for Those Who Believe through the Disciples' Word.

Brown's proposed outline may be criticized in the following ways: 1) Jesus' request for glory in 1-5 was not for his own sake but for his followers' sakes, in order that he might give them eternal life, and the primary function of 6-8 was not primarily to provide a basis for his request for his own glorification but to give the basis for his request for the disciples' preservation and glorification. Schnackenburg (1987:168) is correct when he states that 'the real meaning of [Jesus'] 'glorification' ... [is that] it has the purpose of releasing those forces which bring salvation and mediate life...," and "the participation of believers in Jesus' glory is the aim of the entire prayer" (Schnackenburg 
1987:172, with added emphasis), since the expression "those whom you have given him/me" occurs in vv. 2, 6, 9, and 24, showing that the intention stated in the beginning of the prayer (v. 2) and restated at the beginning of the last section v. 24) is "the really important perspective" (Schnackenburg 1987:171-2). It is true that Jesus' work of revelation among the disciples formed the basis for his request to be restored to his pre-incarnational glory, but his restoration to the Father's presence and glory had as its goal the giving of eternal life and glory to his disciples. Since Jesus' love for his disciples was so great that it was $\epsilon$ ' $\zeta$ $\tau^{\prime} \in \lambda^{\prime} \varsigma \varsigma$, this love is expressed throughout his prayer in Chapter 17, beginning with the first few verses. This prayer is first of all centered in the Father's will, as is everything that the Son did and said, and since it was the Father's will that the whole world be saved, especially those who accepted the Son as their Savior, the prayer is aimed at the highest good of these loved ones who belong to both the Father and the Son, and for whom the Son descended from heaven and is now returning to heaven - all for their salvation and glorification. It is also significant that Jesus gives the following as a reason for speaking this prayer: "But now I am coming to you, and I speak these things in the world so that they may have my joy made complete in themselves" (17.13). Schnackenburg's title for the first division is more appropriate (see below).

Secondly, the title for Brown's second division, "Jesus Prays for Those Whom the Father Has Given Him," is incorrect, since both the first disciples and later disciples are "those whom the Father has given to Jesus," for he will give eternal life to "all whom you have given him" (17.2), and this includes both his original followers and later converts. The title Brown has given to the third division is also inappropriate. The people of whom Jesus is speaking in vv. 20-26 are not only those who believe through the first disciples' word, but all believers. Furthermore, the third division is not a prayer in its entirety; a prayer occurs only in vv. 20-21, followed by four declarative statements in vv. 22-23, 24, 25, and 26, respectively.

Schnackenburg bases his outline on the linguistic structure of the prayer instead of on its contents and concepts. His analysis divides the chapter into six parts (Schnackenburg 1987:169-194): 
1. Jesus' Petition for His Own Glorification to Enable Him to Give Eternal Life to Men 1-5

2. The Reason for Jesus' Petition with Regard to the Disciples 6-11a

3. Jesus' Petition that the Disciples Should Be Kept in God's Being and that They Should Be Kept from the Evil One $11 b-16$

4. Jesus' Petition that the Disciples Should Be Sanctified in the Truth 17-19

5. Jesus' Petition for the Unity of All Believers 20-23

6. Conclusion: The Fulfillment of Believers 24-26

Schnackenburg (1987:169) rightly states that Jesus' request for glorification by the Father is made only for the purpose of giving eternal life to the people the Father has given him (17.2). He suggests that the giving of eternal life is the main theme of Chapter 17, since he considers eternal life and glory to be equivalent (Schnackenburg 1987:168, 192). (Certainly $\delta o ́ \xi \alpha$ and eternal life are closely related, but they are not equivalent.) Sections 3 and 4 comprise the "real intercession," the petition for the keeping of the disciples (vv. 11b-16) and the request that they be sanctified in the truth (vv. 17-19) (Schnackenburg 1987:169). Schnackenburg (1987:185) points out that the petition for their keeping and the request for their sanctification are connected in that the word of God effects separation from the world (14a) as well as sanctification in the truth (17b), and "in the name of God" corresponds to "in the truth." Section 5 develops the request spoken in v. 11b, "that they may be one, even as we are one," and Section 6 is a "vision of the fulfillment," connecting with Section 1 and "completes the whole prayer: the disciples are to share in Jesus' do,xa" (Schnackenburg 1987:169).

\subsection{The structure proposed here}

My proposed schema for Chapter 17 is based on my structural analysis given above and is closer to Schnackenburg's than to any of the other structures.

1. Glorification of the Father and the Son and the Gift of Eternal Life 1-5

2. Revelation of the Father's Name through the Gift of God's Words 6-10

3. The Petition to Keep His People in the Father's Name 11-13 
4. The Petition to Keep His People from the Evil One 14-16

5. The Petition to Sanctify His People in the Father's Word 17-19

6. The Believers' Oneness with God through the Gift of God's Glory 20-23

7. The Believers' Participation in the Glory of Christ and the Continuing Revelation of God 24-26

\subsection{The theme of John 17}

The $\delta \delta^{\prime} \xi \alpha / \delta \circ \xi \alpha \zeta \zeta \epsilon \nu$ word group occurs 8x in Jn 17: 5x in Section 1 (vV. 1-5), once in Section 2 (vv. 6-10), once in Section 6 (vv. 20-23), and once in Section 7 (vv. 24-26). Bultmann (1971:490) comments: "[Glorification] is the first petition of the prayer, and is in fact its whole contents." Since $\delta o ́ \xi \alpha$ may be defined as "the manifestation of God's presence and power" (Dodd 1995:207), and the $\delta 0 \xi \alpha \zeta \epsilon \iota \nu$ of the Son may have the sense "the fuller manifestation of His true nature" (Westcott 1981:238 n.1), the purpose of which is the $\delta 0 \xi \alpha \zeta_{\epsilon} \in \nu /$ 'the fuller manifestation of the Father" (Westcott 1981:238 n.1) (17.1), it is reasonable to conclude that the main subject of Chapter 17 is glorification, i.e. the revelation of God, since in addition to the repeated occurrences of the $\delta \delta^{\prime} \xi \alpha / \delta \circ \xi \alpha \zeta \zeta \in \nu \nu$ word group, several other words occur here, the meanings of which are correlated with the manifestation of

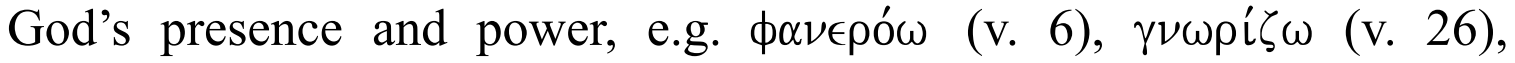

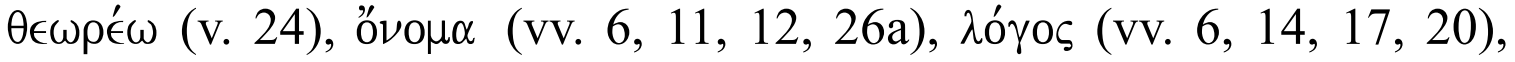
$\dot{\rho} \eta \hat{\mu} \alpha(\mathrm{v} .8)$, and $\dot{\alpha} \lambda \eta^{\theta} \theta \epsilon \iota \alpha$ [vv. $\left.\left.17(2 \mathrm{x}), 19\right)\right]$. The word $\phi \alpha \nu \in \rho o ́ \omega$ is used in the NT in speaking of revelation, and $\gamma \nu \omega \rho \hat{\imath} \zeta \omega$ is a semantically related word (Bultmann/Lührmann 1974). In John, Jesus reveals God's name, i.e. God's being and nature (Schnackenburg 1987:175). God's name represents God, "embodying the (revealed) character of God" (BDB 1906). "I have made your name known" $(17.6,26)$ is "an unusual variant expression for 'I glorified thee' of verse 4. Jesus' earthly work has consisted in revealing the character of the Father, making known

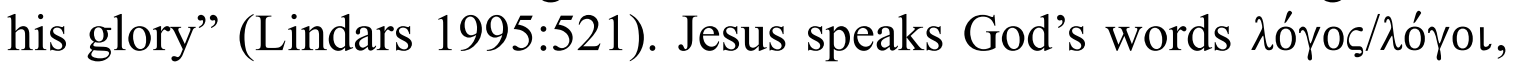
$\dot{\rho} \eta \mu \alpha \tau \alpha, \dot{\alpha} \lambda \hat{\eta} \theta \in \iota \alpha(3.34 ; 12.48-49 ; 14.10 ; 17.8 \mathrm{a}, 14 \mathrm{a}, 17)$, and manifests the works of God $(9.3 ; 10.32 ; 14.10)$ (cf. Schnackenburg 1987:175). "Name and word are closely related" (Barrett 1978:505; cf. Brown 1972:149-155). Name, word, works, and glory are all means by which God reveals himself. When revelation occurs, the $\delta \xi_{\alpha} \alpha$ is sometimes

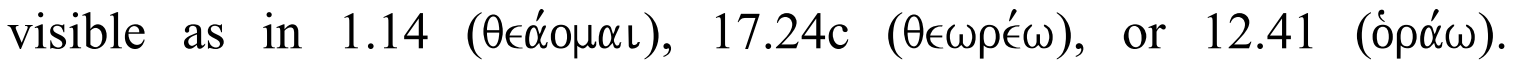
Revelation occurs not only through making God's ǒ $\nu \mu \alpha$ known (17.6a, 


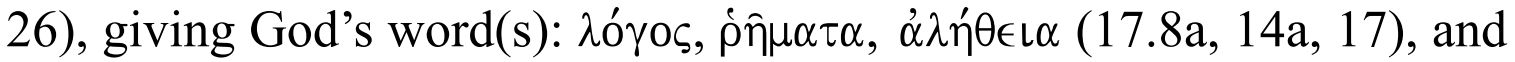

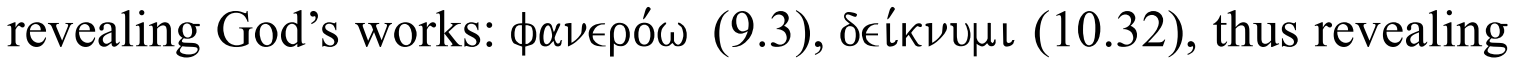
Jesus' own glory or God's glory $(2.11 ; 11.4,40)$, but also through Jesus'

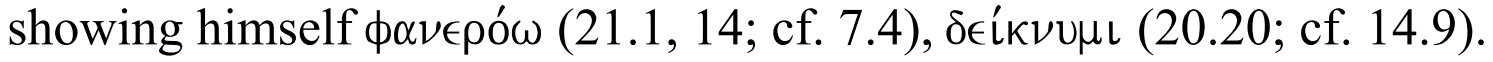

Glorification/revelation is the theme of Chapter 17. The Son has been authorized by the Father to give eternal life to those who belong to them, namely Jesus' disciples and later converts (v. 2). Eternal life is to know the Father and the Son (v. 3), i.e. to receive the revelation of the Father's name/being/character brought by Jesus through his words which are God's words and through himself, the one who has come from God and was sent by God (vv. 6-8, 18, 21, 23, 25). At the same time that the Father is glorified, the Son is also glorified (v. 1, 4, 5), and just as the Son has been given glory, even so the believers are given glory (v. 22). Thus, this prayer is about glorification of the Father, the Son, and their people. Schnackenburg (1987:172) thinks that the "participation of believers in Jesus' glory is the aim of the entire prayer." Bultmann (1971:68-69) believes that the glorification of his followers is the aim of Jesus' entire ministry. "The $\delta o ́ \xi \alpha$ (of the Revealer) consists in what he is as Revealer for men, and he possesses the $\delta$ ó $\xi \alpha$ really - as becomes clear towards the end of the Gospel (12.28; 13.31f; 17.1ff) - when that which he himself is has been actualised in the believer" (Bultmann 1971:68-69).

\subsection{The first division (1-5)}

The address Pa,ter (v. 1) is repeated in v. 5, and the repetition of the request for the glorification of the Son in vv. 1d and 5a indicates that vv. 1-5 form the first division (Schnackenburg 1987:170). Van der Merwe (VE 2002:226-249; cf. Malatesta [Bib 1971:190-214]) sees a chiastic pattern in this unit, as follows, which further shows that vv. 1-5 comprise a complete paragraph:
A

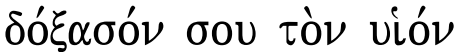
B
C

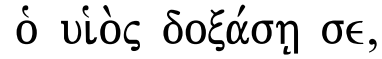
$\mathrm{B}^{\prime}$

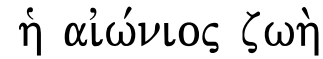
$A^{\prime}$
$\dot{\epsilon} \gamma \omega \dot{\omega} \sigma \epsilon \mathfrak{\epsilon}^{\prime} \delta \delta^{\prime} \xi \alpha \sigma \alpha$

\section{The second division (6-10)}

Vv. 6-10 form the second unit. It begins and ends with words which

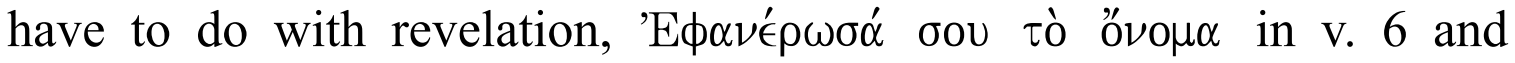


$\delta \in \delta$ 'o $\xi \alpha \sigma \mu \alpha \iota$ in v. 10 . V. 6 is about the revelation of the Father's name, and v. 10 is concerned with the glorification/revelation of the Son. The

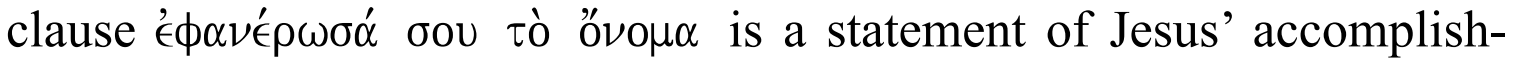
ment in his earthly ministry: the revelation of the Father's name, viz. his character and being (Newman and Nida Translator's Workplace [CD-ROM]).

The revelation of the Father's name (v. 6) is the revealing/ glorifying of the Father himself, and the glorification/revelation of the Son in his disciples (v. 10) is also the revealing/glorifying of the Father, since the Son is the exact likeness of the Father $(8.19 ; 12.45 ; 14.7,9)$ (Bultmann 1971:498; cf. Lindars 1995:521, 523; Beasley-Murray 1987:298; Barrett 1978:505; Westcott 1981:241; Morris 1995:640; Michaels 1998:294; Bruce 1983:330; Moloney 1998:462). The fruitbearing of the disciples will glorify/reveal the Father (15.8). Newman and Nida (Translator's Workplace [CD-ROM]) interpret

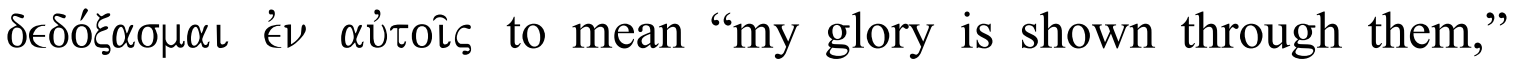
insisting correctly that "to glorify" is not "to bring honor to" but "to reveal the glory of." Schnackenburg (1987:174-175) comments that this section of the prayer contains "in a compressed form, the whole Johannine theology of revelation and the community of salvation..." (Schnackenburg includes v. 11a with vv. 6-10.) Through repetition, heavy emphasis is placed on the fact that the disciples belonged to the Father and were given to Jesus and now belong to both Father and Son (6b-c-d, 9c-d, 10a-b). It is also points out that the disciples have received and kept God's word $(6 \mathrm{e}, 8 \mathrm{~b})$ and have believed in the divine origin of both the words of Jesus (7b) and of Jesus himself (8c-d). Not only are the revelation of the Father and the glorification of the Son (vv. $6 \mathrm{a}$ and $10 \mathrm{c}$ ) in parallelism, but so also are the following:

THEY WERE YOURS, and you gave them to me 6b-c-d

those whom you gave me, because THEY ARE YOURS. All mine are YOURS, and YOURS are mine $(9 c-10 b)$

Now they know that everything you have given me is from you (7a-b)

They ... know in truth that I came from you

and they have believed ${ }^{*}$ that you sent me $(8 \mathrm{c}-\mathrm{d})$.

There is no difference between "they know" and "they have believed." Lindars writes (1995:522): "Both verbs express the appropriation of divine truth with the heart and mind and will." So also Barrett (1978:506); Carson (1991:560). 
The main focus in this second section is on the disciples as those who were chosen to be God's people and to whom the Father and the Son have been revealed through the giving of God's words.

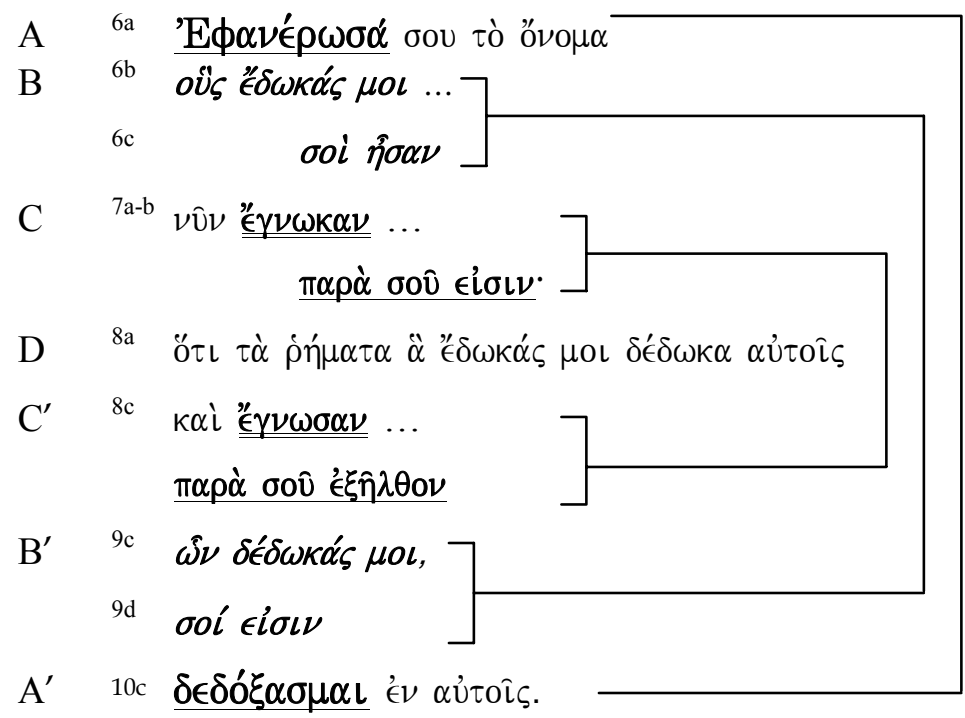

\subsection{The third division (11-13)}

The third section has as a recurrent motif the phrase ' $\epsilon \nu \tau \hat{\varphi}$ кó $\sigma \mu \omega$, which occurs twice in v. 11 and again in v. 13. A second recurring

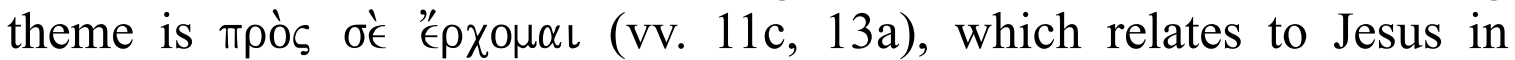
antithesis to the first recurrent theme, which relates first to him, who is no longer in the world, and secondly to the disciples, who remain in the world while Jesus goes to his Father, but the departing teacher leaves his words $\epsilon \nu \tau \hat{\epsilon}$ kó $\sigma \mu \omega$ with his disciples to give them joy (v. 13b). A

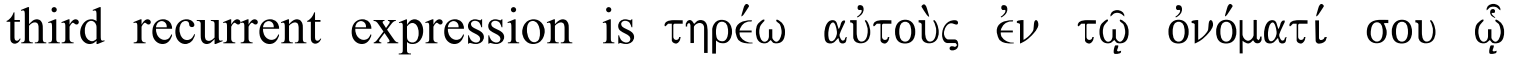
$\delta ' \delta \omega \kappa \alpha \dot{\alpha} \varsigma \mu \mathrm{ol}$, which occurs in 11d and 12a. The three sets of recurring expressions form a framework around the central idea in $11 \mathrm{e}$ " $\nu \alpha \omega \hat{\omega} \sigma \nu$

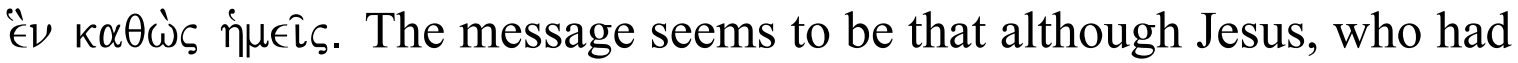
been keeping his followers safe, will no longer be with them in the world, the Father will keep them safe in his being, i.e. "separated from the world as God's own possession" (Barrett 1978:507), in "an inner revelation of the reality of God, an introduction into the sphere of God and a communication of the love and joy of God" (Schnackenburg 1987:181), since "those who believe in Jesus have gained access to the Father through him, the Son" (Schnackenburg 1987:181).

The parallelisms in Section 3 seem to indicate a chiastic structure, with $11 \mathrm{e}$ as the pivotal element. 


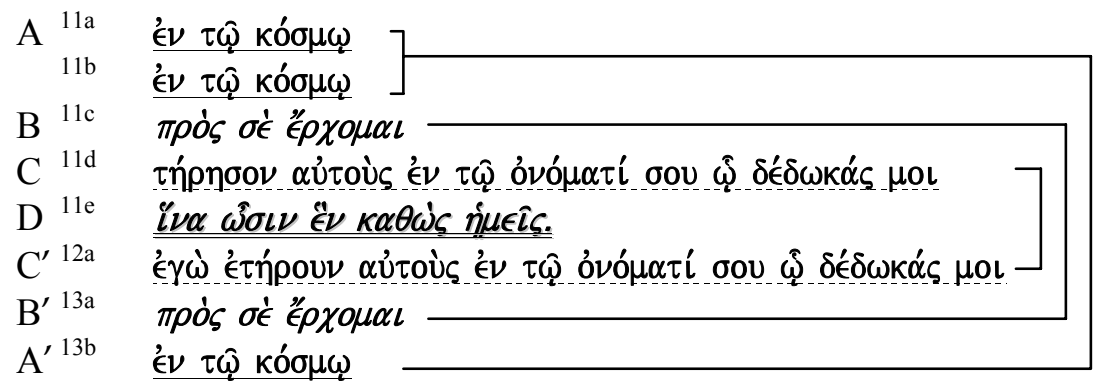

\subsection{The fourth division (14-16)}

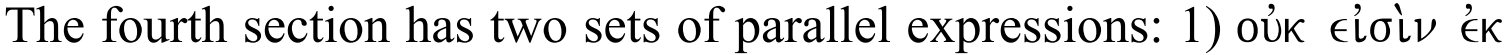

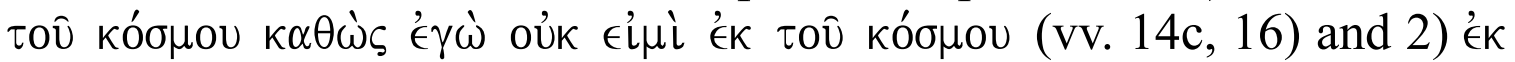

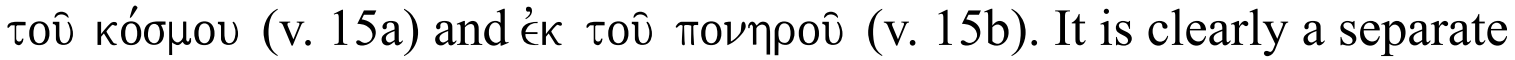
unit from the previous one, since the previous section has the phrase $\epsilon V$ $\tau \hat{\omega}$ кó $\sigma \mu \omega$ at its beginning and at the end, marking it off as a complete

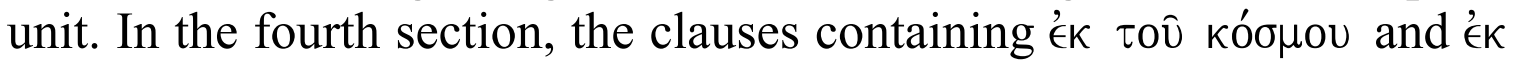

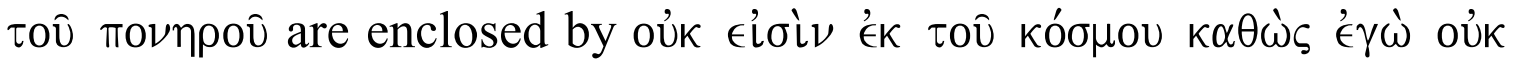

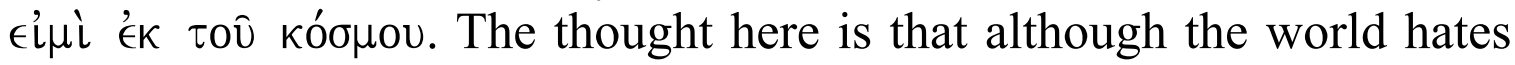
the disciples because God's word has separated them from the world so that they no longer belong to the world, just as Jesus does not belong to the world, Jesus is not asking the Father to take them out of the world but that he keep them out of the reach of the evil one. In the previous section, it was stated that while Jesus was with his people, he kept them in God's name, and not one was lost, except the "son of perdition," and this man (Judas) was lost because he was taken over by Satan. The concern in the fourth section is that no one likewise fall prey to the evil one and be lost.

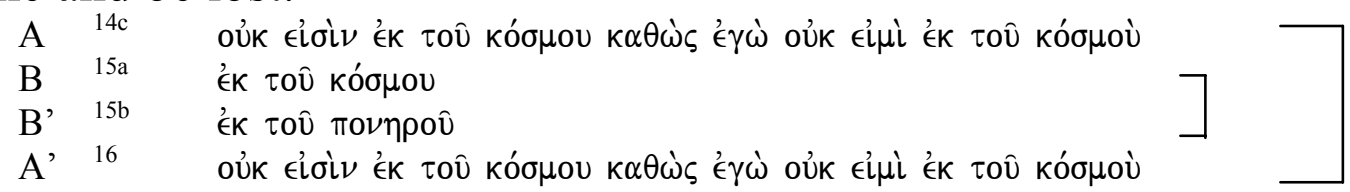

This is the pivotal section of the prayer. The prayer began with the awareness that Jesus' hour had come ("to depart from this world and go to the Father" [13.1]), and he was about to complete his work of glorifying the Father and giving eternal life to his followers. He had commended his disciples to the Father as those belonging to the Father and the Son (17.6-10), and he had petitioned the Father to keep them in his name in order to protect them from the evil one. Jesus' work on earth was completed: He had revealed the Father to the believers whom the Father had given him and had kept them safe in the Father's name, and now he was giving them back into the Father's care, to be protected 
from the devil. The section following this pivotal section will focus on the future work of the disciples (after Jesus' departure), which will be to testify concerning Jesus in order to reveal him to the world, just as Jesus testified concerning the Father to make him known to the world (vv.17-23), followed by a view of the future heavenly glory with Christ (v. 24) and of the continuing glorious state (on earth) of the disciples, who know the name (and being) of the Father through the Son, and have the indwelling presence of the Father's love (and of the Father himself; cf. 14.23) as well as that of the Son (vv. 25-26). The pivotal section, which contrasts the "unworldliness/other-worldliness" of Jesus and his disciples with the world of the evil one and contained a prayer for their deliverance from the evil one (the request to "protect them from the evil one" is similar to the sentence in the Lord's Prayer: "... rescue us from the evil one" [Matt 6.13]), seems to focus on the darkest possible scenario, the realm of Satan, who causes human beings to be lost/destroyed, as "the one doomed to destruction" (17.12 NIV) was lost and perished (17.12 NASB). This dark realm of the evil one is a distinct contrast to the realm of the Holy Father and his Son, whose kingdom is a realm of glory, light and life $(17.5,24$; cf. 1.4-5; 8.12; 9.5; $12.46 ; 3.15-16,36 ; 5.21,24 ; 6.27 ; 11.25 ; 14.6)$. After this pivotal unit, the focus once more is on God's sphere of holiness and truth, and the work of revealing God to the (dark and evil) world (17.17-19), the growth of the body of believers and the growth of the witness to the world (vv. 20-23), the bright prospect of heavenly glory and the blessedness of those who know God and have the indwelling of the divine presence (vv. 24-26).

\subsection{The fifth division (17-19)}

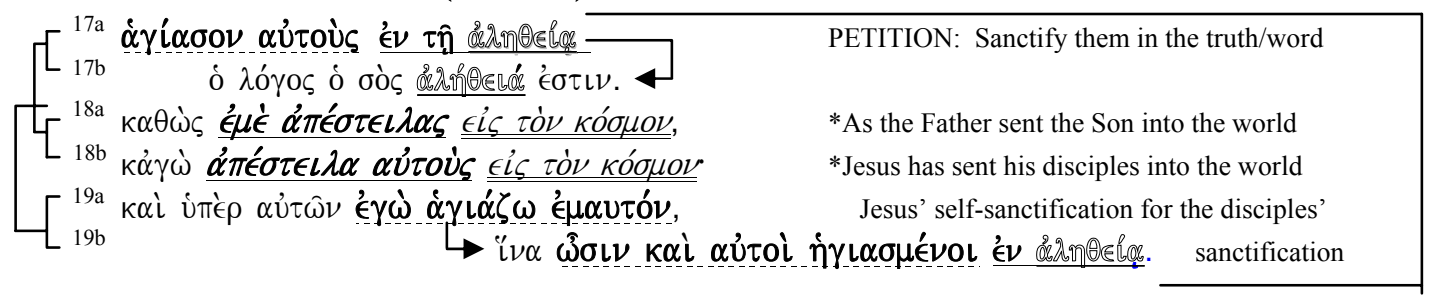

The fifth section (immediately above) has a ring composition, beginning and ending with almost identical sentences:

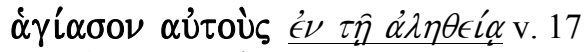

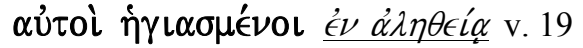


The middle passage (v. 18) consists of two parallel sentences that are closely related and worded similarly:

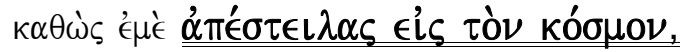

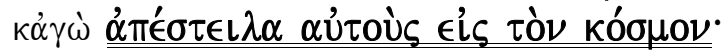

The enclosure of v. 18 by the sentences about sanctification in (the) truth clearly marks off vv. 17-19 as a paragraph.

\subsection{The sixth division (20-23)}

The sixth section (p. 36) begins with v. 20 and ends with v. 23; it consists of a prayer for the oneness of all believers (the first disciples and the converts they win to Christ) in the Father and the Son (vv. 2021 ), followed by a statement that Jesus has given them the $\delta$ ó $\xi \alpha$ so that they may be one as the Father and the Son are one. Thus, both the prayer in vv. 20-21 and the declaration about the gift of $\delta o \xi_{\alpha} \alpha$ in vv. 2223 are about the same theme, the theme of oneness, with the additional objective of winning the world to belief in Jesus as God's emissary. Further discussion of the structure and contents of vv. 20-23 will be given below.

\subsection{The seventh division (24-26)}

The seventh and final section (vv. 24-26, p. 36) contains an expression of desire (v. 24) and a declarative statement (vv. 25-26). Both the desire and the declaration begin with an address to the Father: $\Pi \alpha \dot{\alpha} \epsilon \rho$ in v. 24 and $\pi \alpha^{\prime} \tau \epsilon \rho \delta^{\prime} \iota \kappa \alpha \iota \epsilon$ in v. 25. It is fitting that this farewell prayer should close with a look to the future, to the time when Jesus' followers will also come to the hour when they shall depart this world and go to their heavenly home, where they shall be reunited with Jesus and shall see and share his glory (v. 24). This is the wish Jesus expresses in v. 24. For a brief moment (in v. 25a), Jesus focuses again on the world and its sad plight of not knowing God, and this statement is the pivot of the final section of the prayer. On both sides of this pivot, the subject is Christ and his disciples, first, their heavenly glory (v. 24), and then, the revelation/ glorification of the Father by the Son, which results in the indwelling in believers of the Father's love and of Christ himself (through the Spirit) (vv. 25b-26). (After Jesus' return to the heavenly realm, he sends the Spirit to be another Paraclete to lead the disciples "into all the truth," i.e. "all that the Father has," which is also Jesus" truth, thus revealing/glorifying both the Father and the Son (14.6; 16.13-15). Although there is no mention of the Spirit in Chapter 17, it is through the Spirit that Jesus will make the Father known. See 
Schnackenburg [1987:197]; Barrett [1978:515].) The theme of Christ's heavenly glory, given to him before creation, ties this final unit to the beginning of the prayer (v. 24 to v. 5) as does the concept of knowing God (vv. 25-26 to v. 3).

\section{CONCLUSION}

The prayer for the glorification/revelation of the Father and the Son in vv. 1-5, the objective of which is to make God known so that the recipients of this revelation may have eternal life, is accomplished through the revelation of the Father to the disciples by the giving of God's words, which results in the revelation of Jesus' glory in them (vv. 6-10). Jesus' concern for the disciples whom he leaves behind in the world (at the start of paragraph C, vv. 11-13) is expressed in three petitions: Keep them in your name (11d), keep them from the evil one (15b), and sanctify them in the truth (17a). The desired result of the disciples' being kept in the Father's name and sanctified in the truth is that they may be one with God, as the Father and the Son are one (11e, 21a). This request is repeated in 21a-d, but this time the prayer is for all believers, not only the first disciples. Jesus states in v. 22 that he has given glory to the believers so that they may be one, as the Father and the Son are one, and this oneness is achieved in 26a-d through Jesus' revelation of the Father's name so that God's love and Jesus himself may dwell in the believers.

\section{Consulted literature}

Barrett, C K 1978. The Gospel according to St. John: An introduction with commentary and notes on the Greek text, $2^{\text {nd }}$ ed. Philadelphia: Westminster.

Beasley-Murray, G 1987. John. Vol 36, WBC. Waco: Word.

Black, C C 1996. The grandeur of Johannine rhetoric, in: Culpepper, R A \& Black, C C (eds), Exploring the Gospel of John: In honor of D. Moody Smith. Louisville: Westminster John Knox.

Brown, R E 1970. The Gospel according to John (xiii-xxi). Vol 29A, Anchor Bible. New York: Doubleday.

Brown, R E et al 1972. John and Qumran. London: Geoffrey Chapman.

Brown, F, Driver, S R \& Briggs, C A 1906. S v שם. A Hebrew and English Lexicon of the Old Testament. Boston, New York: Houghton Mifflin.

Bruce, F F 1983. The Gospel of John. Grand Rapids: Eerdmans.

Bultmann, R 1971. The Gospel of John. Philadelphia: Westminster. 


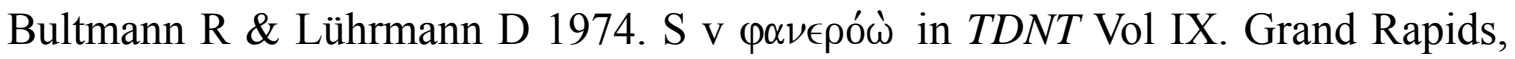
Michigan: Eerdmans.

Cadman, W H 1969. The open heaven. Oxford: Basil Blackwell.

Carson, D A 1991. The Gospel according to John. Leicester: InterVarsity Press.

Dodd, C H 1995. The interpretation of the fourth gospel. Cambridge: Cambridge University Press.

Jordan, J E 1965. Using rhetoric. New York: Harper \& Row, 121.

Käsemann, E 1968. The testament of Jesus: A study of the Gospel of John in the light of chapter 17. Philadelphia: Fortress.

Kysar, R 1992. S v "John the Gospel of" in: Anchor Bible Dictionary Vol. 3. New York: Doubleday.

Lagrange, M-J 1995. Evangile selon Saint Jean. Paris: Gabalda.

Lindars, B 1995. The Gospel of John. New Century Bible Commentary. London: Marshall, Morgan \& Scott.

Louw, J P 1982. Semantics of New Testament Greek. Atlanta: Scholars Press.

Malatesta, E 1971. The literary structure of John 17. Bib 52, 190-214.

Michaels, J R 1998. John. Vol 4, NIBCNT. Carlisle: Paternoster.

Moloney, F 1998. The Gospel of John. Collegeville, Minn: Liturgical Press.

Morris, L 1995. The Gospel according to John. NICNT. Rev ed. Grand Rapids: Eerdmans.

Newman, B and Nida E A. A translator's handbook on the Gospel of John in Translator's workplace [CD-ROM]. United Bible Societies.

Reventlow, H G, 1999. Basic issues in the interpretation of Isaiah 53, in: Bellinger, W H Jr \& Farmer, W R (eds), Jesus and the Suffering Servant. Harrisburg: Trinity Press International.

Schnackenburg, R 1987. The gospel according to St. John, vol. 3. New York: Crossroad.

Smith, D M 1965. The Order and Composition of the Fourth Gospel. New Haven: Yale University Press.

Van der Merwe, D 2002. The glory-motif in John 17.1-5: An exercise in biblical semantics. VE 23, 226-249.

Van der Watt, J G \& Kruger, Y. Some considerations on Bible translation as complex process. [CD-ROM].

Westcott, B F 1981. The Gospel according to St. John. Grand Rapids: Eerdmans 